\title{
A case of breast cancer involving a ventriculoperitoneal shunt
}

\author{
Mirei Kamei ${ }^{1 *}$, Nobuyuki Kikuchi ${ }^{1}$, Homare Ichimura $^{2}$, Masao Chujo $^{3}$, Yoshiaki Takahashi ${ }^{1}$ and Kenji Sugio ${ }^{4}$
}

\begin{abstract}
An 84-year-old woman was examined for an enlargement of an induration in the left breast. A ventriculoperitoneal shunt had been placed for postoperative normal pressure hydrocephalus of a cerebral hemorrhage, and it had penetrated the mass according to the computed tomography findings. Breast cancer was diagnosed after a close examination; however, close observation was selected because her family rejected treatment. She developed somnolence 7 months after the initial examination, and ventricular dilatation and expansion of the low-density region around the ventricle were noted on computed tomography, suggesting that the enlarged tumor had excluded the shunt and caused obstruction. The growth of breast carcinoma involving a shunt tube can be the cause of obstruction of a ventriculoperitoneal shunt. Our findings suggest that a breast lesion should be evaluated at both pre- and postoperation.
\end{abstract}

Keywords: Breast cancer, Ventriculoperitoneal shunt, Shunt malfunction

\section{Background}

Ventriculoperitoneal (VP) shunt operation is the common neurosurgical procedure for hydrocephalus. Although a VP shunt is frequently associated with complications, the complications related to the breast are rare according to the previous literature. These include cerebrospinal fluid (CSF) pseudocysts, CSF galactorrhea, and the migration of the shunt tube inside the silicone breast implant. We herein present a case of breast cancer involving a VP shunt with a review of the pertinent literature.

\section{Case presentation}

The patient was an 84-year-old woman in whom a VP shunt had been placed for normal pressure hydrocephalus after a cerebral hemorrhage at 69 years of age, and she was in a state of dysbasia with an Eastern Cooperative Oncology Group (ECOG) performance status (PS) of 3. While staying in a facility, a mass in the left breast had been noted on a visiting examination by the primary care hospital staff. Since the mass was enlarged, she was examined by a

\footnotetext{
* Correspondence: mirei65@oita-u.ac.jp

${ }^{1}$ Department of Surgery, Shin-beppu Hospital, 3898 Tsurumi, Beppu, Oita

874-5593, Japan

Full list of author information is available at the end of the article
}

physician. A $3-\mathrm{cm}$ hard mass retracting the dark red skin was palpated on the medial side of the left breast (Fig. 1). Differentiation of a subcutaneous malignant tumor was also considered; however, left breast cancer was suspected according to the ultrasonography findings, and fine needle aspiration cytology (FNAC) was performed. The cytological findings showed increases in the nucleus/cytoplasm $(\mathrm{N} / \mathrm{C})$ ratio and chromatin content, an aggregation of atypical cells, and intracytoplasmic lumen. According to these findings, the mass was diagnosed as infiltrating breast cancer. The carcinoembryonic antigen (CEA) level was $8.0 \mathrm{ng} / \mathrm{ml}$, cancer antigen15-3 (CA15-3) was $42.2 \mathrm{U} / \mathrm{ml}$, and breast carcinomaassociated antigen 225 (BCA225) was $210 \mathrm{U} / \mathrm{ml}$, all of which were elevated. On whole-body computed tomography (CT), the mass was observed to involve the VP shunt (Fig. 2) and infiltrated the mammary gland over the skin; however, axillary lymph node metastasis and distant metastasis were not observed. Because damage to the shunt due to a needle puncture was a concern, the patient was referred to the neurosurgery department of our hospital; however, there was no problem with the shunt. En bloc resection of the VP shunt and breast was recommended to prevent problems with the shunt, but close observation was

\section{实 Springer}

(c) 2016 Kamei et al. Open Access This article is distributed under the terms of the Creative Commons Attribution 4.0 International License (http://creativecommons.org/licenses/by/4.0/), which permits unrestricted use, distribution, and reproduction in any medium, provided you give appropriate credit to the original author(s) and the source, provide a link to the Creative Commons license, and indicate if changes were made. 


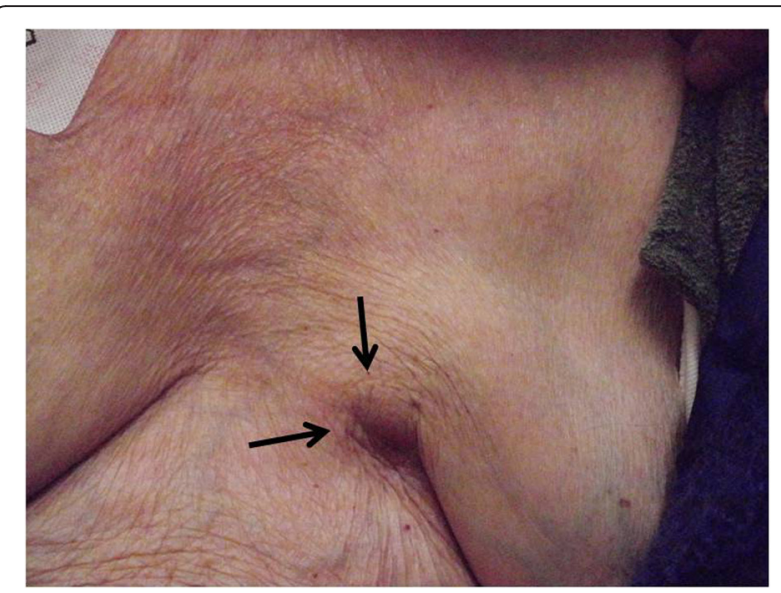

Fig. 1 A mass accompanied by redness was present in the medial region of the left breast

selected because her family rejected any treatment. At 7 months after the initial examination, the tumor marker levels were higher: CEA, $9.5 \mathrm{ng} / \mathrm{ml}$; CA15-3, $56 \mathrm{U} / \mathrm{ml}$; and BCA225, $200 \mathrm{U} / \mathrm{ml}$. Skin redness and lethargy developed, and tumor enlargement was observed. A CT scan of the head showed dilated ventricles and the enlargement of periventricular lucency, suggesting that the tumor enlargement caused the obstruction (Fig. 3a, b). Three months later, the patient became bedridden and suffered from aspiration pneumonia due to dysphagia.

\section{Discussion}

Hydrocephalus can be developed in all generations. Many hydrocephalus patients receive a CSF shunt, which is applied to 16,000 patients annually in Japan, and a VP shunt is most frequently placed. The average lifespan of Japanese women has exceeded 80 years, and the elderly population is increasing. Therefore, the number of shunt operations performed annually is

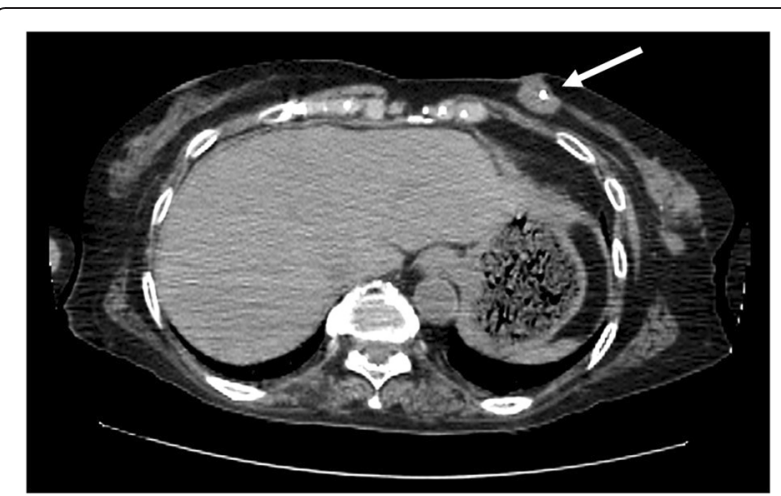

Fig. 2 A CT scan showed that the tumor involved the VP shunt likely to increase due to an increase in elderly patients. On the other hand, the incidence of breast cancer has continuously increased in Japan. The number of breast cancer patients with CSF shunts may be increasing. Complications frequently associated with a VP shunt, including shunt obstruction, infection, overdrainage of CSF, and perforation of the gastrointestinal tract, gallbladder, vagina, and abdominal wall at the umbilicus, have also been reported [1]. Regarding complications associated with the mammary gland, CSF pseudocysts due to the leakage of CSF from the catheter shunt obstruction, CSF galactorrhea, and shunt migration of the VP shunting catheter under or within silicone breast implants have been previously reported; however, they are considered to be very rare [2-5].

In the present patient, breast cancer involving a VP shunt was observed, which is very rare and only three cases have been previously reported in the English literature [6-8] (Table 1). All patients had advanced age (67 to 88 years of age). As a person ages, atrophy of the breast become progressive and fat tissue replaces the breast tissue. Therefore, a shunt can easily insert into the breast tissue that has been replaced with fat tissue in cases of shunt operation. We speculate that this is the cause of breast-related shunt complications. Since a silicone catheter is very soft, it is unlikely that the shunt catheter pierced the breast cancer. The cancer may have developed and grew around and involved the shunt catheter. In the published literature, only one case of breast cancer demonstrated neurologic symptoms due to shunt trouble [6]. This previous case was detected at screening without symptoms; in another case and our case, a skin lesion was noted without other neurologic symptoms [7, 8]. Therefore, it is important to perform breast cancer screening before and after the shunt operation. FNAC was performed for the diagnosis of breast cancer in three cases including our case. In our case, FNAC was performed before CT screening, while in the other two cases, it was performed after CT screening or magnetic resonance imaging (MRI) scan. Therefore, the positional relationship between the tumor and shunt tube should be confirmed before aspiration in cases in which the shunt tube and tumor are on the same side of the chest.

Roka et al. reported consciousness disturbance due to hydrocephalus symptoms induced by catheter obstruction by a breast cancer mass [6]. Our case was not treated, and stenosis by catheter compression occurred 7 months after the initial examination. The ventricle was dilated and periventricular lucency expanded, suggesting the aggravation of hydrocephalus. However, the PS and consciousness of our patient 

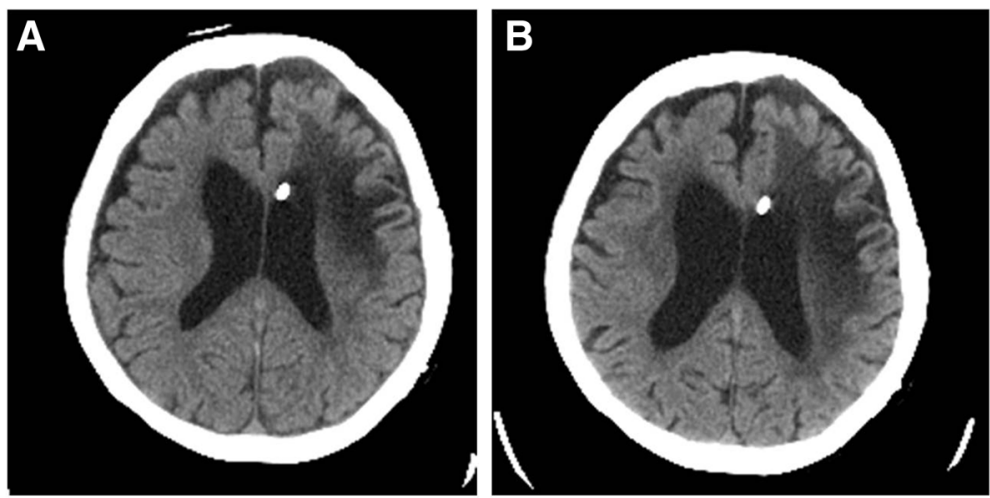

Fig. 3 Brain CT showed that the ventricle was more dilated and the low-density region around the ventricle had expanded within 7 months (b) after the initial visit to our hospital (a)

was poor from the first visit, thus it was difficult to determine worsening of her condition, except that she was somnolent and bedridden. If the breast cancer was discovered earlier, there might be a possibility that the shunt tube had not been involved with breast cancer. Taken together, partial resection of the breast under local anesthesia may be a treatment of choice leading to convince her family. Therefore, this outcome may have been changed.

Regarding breast cancer operation, resection of the breast cancer, including shunt placement and rerouting of the shunt, is necessary to prevent dissemination through the catheter by a breast surgeon and neurosurgeon in close cooperation with one other. There was no effective means to treat this case, while her family did not want us to perform any invasive treatments or diagnostic procedures. However, endocrine therapy would have been one treatment option for this patient. Various diagnostic procedures, including US-guided biopsy and incision biopsy should be performed in such cases to obtain tissue samples and thereby identify the intrinsic subtype. For cases with skin involvement, intervention can also be performed without damaging the shunt tube in order to obtain subcutaneous tissue that may have become infiltrated with cancer cells. Even if such tissue sampling proves to be impossible, treating such patients with endocrine therapy is still one therapeutic alternative.

In any case, regular breast cancer screening after shunt operation is necessary.

\section{Conclusions}

We herein encountered a very rare case of breast cancer involving a VP shunt. In Japan, the incidence of breast cancer and the number of elderly individuals have increased. An evaluation for breast cancer before shunt placement, in addition to an examination of the body surface, and follow-up breast cancer screening after shunt placement is necessary.

\section{Consent}

Written informed consent was obtained from the patient for publication of this case report and any accompanying images. A copy of the written consent is available for review by the Editor-in-Chief of this journal.

Table 1 Cases in the literature of breast cancer involving a VP shunt

\begin{tabular}{|c|c|c|c|c|c|c|c|}
\hline Author & $\begin{array}{l}\text { Age } \\
\text { (years) }\end{array}$ & Past history & Region of the tumor & $\begin{array}{l}\text { Tumor } \\
\text { size }\end{array}$ & $\begin{array}{l}\text { Neurologic symptoms } \\
\text { (other symptoms) }\end{array}$ & $\begin{array}{l}\text { Examination } \\
\text { of the tumor }\end{array}$ & Treatment \\
\hline Roka [6] & 70 & $\mathrm{NPH}$ & Rt. upper inner quadrant & $8.0 \mathrm{~cm}$ & $\begin{array}{l}\text { Headache, drowsiness, } \\
\text { altered sensorium }\end{array}$ & FNAC & $\begin{array}{l}\text { Radical mastectomy/ } \\
\text { rerouting of the VP shunt }\end{array}$ \\
\hline Lee [7] & 88 & Head trauma & Rt. upper inner quadrant & $1.7 \mathrm{~cm}$ & $\begin{array}{l}\text { No symptoms (hard skin } \\
\text { lesion) }\end{array}$ & Biopsy of skin & $\begin{array}{l}\text { No operation/hormone } \\
\text { therapy }\end{array}$ \\
\hline Jain [8] & 67 & Ependymoma & Rt. upper inner quadrant & $1.3 \mathrm{~cm}$ & $\begin{array}{l}\text { No symptoms (breast } \\
\text { screening) }\end{array}$ & FNAC & $\begin{array}{l}\text { Wide local excision, SLNB/ } \\
\text { rerouting of the VP shunt }\end{array}$ \\
\hline Present case & 84 & $\begin{array}{l}\text { Cerebral } \\
\text { hemorrhage }\end{array}$ & Lt. under inner quadrant & $3.0 \mathrm{~cm}$ & $\begin{array}{l}\text { No symptoms (hard skin } \\
\text { lesion) }\end{array}$ & FNAC & No treatment \\
\hline
\end{tabular}




\section{Abbreviations}

BCA225: breast carcinoma-associated antigen225; CA15-3: cancer antigen15-3; CEA: carcinoembryonic antigen; CSF: cerebrospinal fluid; CT: computed tomography; ECOG: Eastern Cooperative Oncology Group; FNAC: fine needle aspiration cytology; MRl: magnetic resonance imaging; N/C: nucleus/ cytoplasm; PS: performance status; VP shunt: ventriculoperitoneal shunt.

\section{Competing interests}

The authors declare that they have no competing interests.

\section{Authors' contributions}

KS proofread the paper. MK was responsible for the patient and wrote the paper. $\mathrm{HI}$ evaluated the neurological examination. NK and YT performed the literature search. MC obtained the patient's consent. All authors read and approved the final manuscript.

\section{Author details}

'Department of Surgery, Shin-beppu Hospital, 3898 Tsurumi, Beppu, Oita 874-5593, Japan. '2Department of Neurosurgery, Shin-beppu Hospital, Beppu, Oita 874-5593, Japan. ${ }^{3}$ Kitsuki Central Hospital, 120 Kitsuki, Kitsuki, Oita, Japan. ${ }^{4}$ Department of Thoracic and Breast Surgery, Faculty of Medicine, Oita University, 1-1 Idaigaoka, Hasama, Yufu, Oita 879-5503, Japan.

Received: 8 September 2015 Accepted: 2 February 2016 -

\section{References}

1. Blount JP, Campbell JA, Haines SJ. Complications in ventricular cerebrospinal fluid shunting. Neurosurg Clin N Am. 1993;4:633-56.

2. Dayananda L, Karthik GA, Santhosh Kumar DG, Yameen. Case report: CSF pseudocyst in the breast. Indian J Radiol imaging. 2009;19:291-2.

3. Lee SC, Chen JF, Tu PH, Lee ST. Cerebrospinal fluid galactorrhea: a rare complication of ventriculoperitoneal shunting. Journal of Clinical Neuroscience. 2008;15:698-700.

4. Mudo ML, Amantea AV, Joaquim AF, Cavalheiro S. Distal migration of ventriculoperitoneal shunting catheter under silicon breast implant. Arq Neuropsiquiatr. 2009;67:697-8.

5. Schrot RJ, Ramos-Boudreau C, Boggan JE. Breast-related CSF shunt complications: literature review with illustrative case. Breast J. 2012;18: 479-83.

6. Roka YB, Gupta R, Bajracharya A. Unusual cause for ventriculoperitoneal shunt failure: carcinoma breast compressing distal catheter. Neurol India. 2010;58:662-4.

7. Lee D, Cutler B, Roberts S, Manghisi S. Multi-centric breast cancer involving a ventriculoperitoneal shunt. Breast J. 2010;16:653-5.

8. Jain YK, Kokan JS. An interesting case of screen-detected breast cancer encasing a ventriculoperitoneal shunt. BMJ Case Rep. 2013; doi : 10.1136/ bcr-2012-007894.

\section{Submit your manuscript to a SpringerOpen ${ }^{\mathcal{O}}$ journal and benefit from:}

- Convenient online submission

- Rigorous peer review

- Immediate publication on acceptance

- Open access: articles freely available online

- High visibility within the field

- Retaining the copyright to your article 